Matematikai Közlemények

VIII. kötet, 2020

doi:10.20312/dim.2020.06

\title{
Másodrendű differenciálegyenletes modellek
}

\author{
Horváth-Szováti Erika \\ Soproni Egyetem Matematikai Intézet \\ horvath-szovati.erika@uni-sopron.hu
}

\begin{abstract}
ÖSSZEFOGLALÓ. A természettudományokban sok probléma megoldásához másodrendủ differenciálegyenletek felírása és megoldása szükséges. Ezek szemléltetése a hallgatók erősen korlátozott matematikai eszköztára miatt csak alaposan végiggondolt, és a lehetőségekhez mérten maximálisan leegyszerüsített feladatok segítségével lehetséges. Az itt felsorolásra kerülő példák ebben nyújthatnak segítséget.
\end{abstract}

\begin{abstract}
Here are simple practical examples that highlights the practical application of second order differential equations. To solve these math problems, students need only a little background knowledge. By these exercises, the students can see that differential equations are essential in different sciences.
\end{abstract}

\section{Bevezetés}

A természettudományokban sok folyamat leírása csak differenciálegyenletekkel lehetséges. Ezen belül a másodrendü differenciálegyenletek elöfordulása is nagyon gyakori. Egy egyenletesen változó mozgás leírása (pl. szabadesés légellenállással), egy RLC körben az áramforrás elektromotoros erejének időbeli változása, egy hővezető rúd hőmérsékletének változása, stb. mind-mind másodrendü differenciálegyenletekkel leírható problémák. A rezgések differenciálegyenletei is ebbe a csoportba tartoznak, amelyeket a környezetmérnök hallgatók a hangterjedés vizsgálata, a rezgéscsillapítás lehetőségei, a zaj- és rezgésvédelem témakörökben használnak. Tudományos kutatásaik, diplomamunkájuk során szintén találkozhatnak olyan irodalommal, amelyben másodrendü differenciálegyenletek szerepelnek. BSc szinten egy ilyen egyenlet önálló felírása nem cél, azonban az értelmezés, következtetések levonása elvárható. A másodrendű differenciálegyenletek alább összegyüjtött alkalmazásai olyan egyszerü példák, amelyek a csekélyebb matematikai háttértudással rendelkező hallgatókat is segíthetik abban, hogy a témakör jelentőségét megértsék. Itt csak kétféle másodrendü differenciálegyenlet típussal foglalkozunk, azzal a kettővel, amelyeket a BSc képzésben tanítunk. Bízunk abban, hogy az alábbi kidolgozott példák elemzése után a hallgatók más típusú differenciálegyenletek önálló értelmezésétől sem riadnak majd vissza.

\section{Egyenletesen változó mozgás leírása (két egymást követő integrálással megoldható feladatok)}

2.1. feladat. Egy gépkocsi $72 \frac{\mathrm{km}}{\mathrm{h}}$ sebességről egyenletesen lassulva $10 \mathrm{~s}$ alatt áll meg. Mekkora utat tesz meg ezalatt? Jelöljük $x(t)$-vel a megtett utat az idö függvényében. Mivel a gépkocsi egyenletesen lassul, így $\ddot{x}(t)=a$, ahol $a \in \mathbb{R}$. (Megj.: Fizikából tudjuk, hogy az $x(t)$ függvény idő szerinti első deriváltja a sebesség, a második deriváltja pedig a gyorsulás.) 
Megoldás. A feladatban adott

$$
\ddot{x}(t)=a
$$

differenciálegyenletből indulunk ki, kétszer integráljuk mindkét oldalt az idő szerint:

$$
\begin{gathered}
\dot{x}(t)=a t+C_{1} \\
x(t)=a \frac{t^{2}}{2}+C_{1} t+C_{2}, \quad C_{1}, C_{2} \in \mathbb{R} .
\end{gathered}
$$

A feladat szövegéböl a következő három kezdeti feltétel adódik:

- A test által megtett fékút a fékezés kezdetekor, vagyis a $t=0 \mathrm{~s}$ időpillanatban $0 \mathrm{~m}$ volt:

$$
x(0)=0 \text {. }
$$

- A test a $t=0 \mathrm{~s}$ időpillanatban $72 \frac{\mathrm{km}}{\mathrm{h}}=20 \frac{\mathrm{m}}{\mathrm{s}}$ sebességgel mozgott:

$$
\dot{x}(0)=20 \text {. }
$$

- A test $10 \mathrm{~s}$ alatt állt meg, vagyis a sebessége ekkor $0 \frac{\mathrm{m}}{\mathrm{s}}$ volt:

$$
\dot{x}(10)=0 \text {. }
$$

Írjuk be a kezdeti feltételeket a differenciálegyenlet általános megoldásába, illetve az első deriváltba!

$$
\left.\begin{array}{rl}
0 & =a \cdot \frac{0^{2}}{2}+C_{1} \cdot 0+C_{2} \\
20 & =a \cdot 0+C_{1} \\
0 & =a \cdot 10+C_{1}
\end{array}\right\}
$$

Az egyenletrendszer megoldása: $C_{1}=20, C_{2}=0, a=-2$. Ezeket visszahelyettesítve az általános megoldásba megkapjuk a kezdeti feltételeknek megfelelő partikuláris megoldást:

$$
x_{p}(t)=-2 \frac{t^{2}}{2}+20 t
$$

Ebböl meg tudjuk határozni a keresett utat:

$$
x_{p}(10)=-2 \frac{10^{2}}{2}+200=100(m) .
$$

Megjegyzés. Az $x(t)=a \frac{t^{2}}{2}+C_{1} t+C_{2}\left(C_{1}, C_{2} \in \mathbb{R}\right)$ általános megoldásban $C_{1}=v_{0}, C_{2}=$ $0, a$ : a test gyorsulása (vagy lassulása). Tehát valójában a fizikából ismert $s=\frac{a}{2} t^{2}+v_{0} t$ képlet, amely segítségével a $v_{0}$ kezdősebességgel rendelkező, $a(>0)$ egyenletesen gyorsuló (vagy $a(<0)$ egyenletesen lassuló) test által $t$ idő alatt megtett utat szoktuk kiszámolni. 
2.2. feladat. Egy $30^{\circ}$-os hajlásszögü lejtőre helyezett fakocka álló helyzetből indulva, kezdősebesség nélkül csúszik a lejtő tetejéről lefelé. Legyen $x(t)$ a test által megtett út az idő függvényében, $\alpha$ a lejtő hajlásszöge, $g$ a gravitációs gyorsulás ( $\left.g \approx 10 \frac{m}{s^{2}}\right)$, és $\mu$ a test és a lejtő anyaga közötti csúszási súrlódási együttható $(\mu=0,5)$. Ekkor Newton II. törvénye szerint a test elmozdulását az idő függvényében leíró differenciálegyenlet: $\ddot{x}(t)=g(\sin \alpha-\mu \cos \alpha)$. Mekkora utat tesz meg a test az indulástól számított 3 másodperc alatt?

Megoldás. A feladatban adott differenciálegyenlet másodrendü, hiányos. Két egymást követő integrálással megoldható:

$$
\begin{gathered}
\ddot{x}(\mathrm{t})=\mathrm{g}(\sin \alpha-\mu \cos \alpha), \\
\dot{x}(\mathrm{t})=\mathrm{g}(\sin \alpha-\mu \cos \alpha) \cdot t+C_{1}, \\
x(\mathrm{t})=\mathrm{g}(\sin \alpha-\mu \cos \alpha) \cdot \frac{t^{2}}{2}+C_{1} t+C_{2}, \quad C_{1}, C_{2} \in \mathbb{R} .
\end{gathered}
$$

A test álló helyzetből, kezdősebesség nélkül kezd el csúszni a lejtő tetejéről lefelé, azaz adottak a következő kezdeti feltételek: $x(0)=0, \dot{x}(0)=0$. Ezeket az általános megoldásba, illetve annak deriváltjába visszahelyettesítve:

$$
\left.\begin{array}{l}
0=\mathrm{g}(\sin \alpha-\mu \cos \alpha) \cdot 0+C_{1} \\
0=\mathrm{g}(\sin \alpha-\mu \cos \alpha) \cdot \frac{0^{2}}{2}+C_{1} \cdot 0+C_{2}
\end{array}\right\} .
$$

Az egyenletrendszer megoldása: $C_{1}=0, C_{2}=0$. A konstansokat behelyettesítve az általános megoldásba a kezdeti feltételeknek megfelelő partikuláris megoldást kapjuk:

$$
x_{p}(\mathrm{t})=\mathrm{g}(\sin \alpha-\mu \cos \alpha) \cdot \frac{t^{2}}{2} .
$$

Ebből kiszámítható a test által 3 másodperc alatt megtett út:

$$
x_{p}(3)=\frac{9}{2} \cdot 10 \cdot\left(\sin 30^{\circ}-0,5 \cdot \cos 30^{\circ}\right) \approx 3,01(m) .
$$

\section{Harmonikus rezgések (állandó együtthatós, másodrendû, lineáris differenciálegyenletek)}

3.1. feladat. Egy rugóra akasztott test harmonikus rezgőmozgást végez, jelöljük $x(t)$-vel a kitérés-idő függvényt. Harmonikus rezgőmozgás esetén a test gyorsulása arányos és ellentétes irányú a kitéréssel, azaz: $\ddot{x}(t)=-\omega^{2} \cdot x(t)$. (Az $\omega$ neve körfrekvencia, továbbá $\omega^{2}=\frac{D}{m}$, ahol $D$ a rugóállandó, $\mathrm{m}$ a test tömege.) A test kitérése $t=0$ másodperc időpillanatban 0 méter, a sebessége pedig ugyanekkor $3 \frac{\mathrm{m}}{\mathrm{s}}$. Adjuk meg a test kitérését az idő függvényében, ha $\omega=1\left(\frac{1}{s}\right)$ ! Határozzuk meg a test kitérését a $t=\frac{\pi}{6}$ másodperc időpillanatban! 
Megoldás. A feladatban egy homogén, állandó együtthatós, másodrendü, lineáris differenciálegyenlet adott, amelybe behelyettesítve $\omega$ értékét, majd nullára rendezve az

$$
\ddot{x}(t)+x(t)=0
$$

egyenletet kapjuk. Az ebből felírható karakterisztikus egyenlet (ahol $x(t)=e^{\lambda t}$ ), illetve annak gyökei:

az általános megoldás pedig

$$
\begin{gathered}
\lambda^{2}+1=0, \\
\lambda= \pm i
\end{gathered}
$$

$$
x(t)=C_{1} e^{0 t} \sin t+C_{2} e^{0 t} \cos t=C_{1} \sin t+C_{2} \cos t, \text { ahol } C_{1}, C_{2} \in \mathbb{R} .
$$

Mivel az egyik kezdeti feltétel a sebességet adja meg egy időpillanatban, így szükség van a sebesség-idő függvényre is, amely a kitérés-idő függvény deriváltja:

$$
\dot{x}(t)=C_{1} \cos t-C_{2} \sin t .
$$

A partikuláris megoldást úgy kapjuk meg, hogy behelyettesítjük a kezdeti feltételeket az általános megoldásba, illetve annak deriváltjába. A szövegben megadottak alapján a test kitérése $t=0$ másodperc időpillanatban 0 méter, a sebessége pedig ugyanekkor $3 \frac{\mathrm{m}}{\mathrm{s}}$. Eszerint $x(0)=0$ és $\dot{x}(0)=3$. Ebböl a

$$
\left.\begin{array}{l}
C_{1} \cdot 0+C_{2} \cdot 1=0 \\
C_{1} \cdot 1-C_{2} \cdot 0=3
\end{array}\right\}
$$

egyenletrendszer adódik, amelyböl $C_{1}=3$ és $C_{2}=0$, tehát a kezdeti feltételeknek megfelelő partikuláris megoldás

$$
x_{p}(t)=3 \sin t
$$

A $t=\frac{\pi}{6}$ másodperc időpillanatban a test az egyensúlyi helyzettől 1,5 méterre lesz:

$$
x\left(\frac{\pi}{6}\right)=3 \sin \frac{\pi}{6}=1,5
$$

3.2. feladat. Egy harmonikus rezgőmozgást végző testre a közegellenállás csillapításként hat, amely a sebességgel arányos, és azzal ellentétes irányú. Ekkor a test mozgását leíró differenciálegyenlet: $\ddot{x}(t)=-\omega^{2} \cdot x(t)-k \dot{x}(t)$, ahol $x(t)$ a test kitérése az idő függvényében, az $\omega$ arányossági tényező a körfrekvencia (ld. előző feladat), a $k(>0)$ pedig a csillapítási konstans, melynek értéke a feladatban $k=10 \frac{\mathrm{Ns}}{\mathrm{m}}$. A test kitérése $t=0 \mathrm{~s}$ időpillanatban 0 méter, a sebessége ugyanekkor $12 \frac{\mathrm{m}}{\mathrm{s}}$. Adjuk meg a test kitérését az idő függvényében, ha $\omega=4 \frac{1}{s}$ ! Határozzuk meg a test kitérését a $t=1 \mathrm{~s}$ időpillanatban! 
Megoldás. Hasonlóan oldjuk meg, mint az előző feladatot. A karakterisztikus egyenlet (ahol $x(t)=e^{\lambda t}$ ), illetve annak gyökei:

$$
\begin{gathered}
\ddot{x}(t)+10 \dot{x}(t)+16 x(t)=0, \\
\lambda^{2}+10 \lambda+16=0, \\
\lambda=\frac{-10 \pm \sqrt{100-4 \cdot 16}}{2},
\end{gathered}
$$

amelyből $\lambda_{1}=-2, \lambda_{2}=-8$, az általános megoldás pedig

$$
x(t)=C_{1} e^{-2 t}+C_{2} e^{-8 t}, \text { ahol } C_{1}, C_{2} \in \mathbb{R} .
$$

Ismét szükség van a sebesség-idő függvényre is, emiatt deriváljuk az előbbi függvényt:

$$
\dot{x}(t)=-2 C_{1} e^{-2 t}-8 C_{2} e^{-8 t} .
$$

A test kitérése $t=0 \mathrm{~s}$ időpillanatban 0 méter, a sebessége pedig ugyanekkor $12 \frac{\mathrm{m}}{\mathrm{s}}$, vagyis $x(0)=0$ és $\dot{x}(0)=12$. Ezeket behelyettesítve az általános megoldásba, illetve annak deriváltjába:

$$
\left.\begin{array}{c}
C_{1}+C_{2}=0 \\
-2 C_{1}-8 C_{2}=12
\end{array}\right\}
$$

Ebből $C_{1}=2$ és $C_{2}=-2$ adódik, tehát a kezdeti feltételeknek megfelelő partikuláris megoldás

$$
x_{p}(t)=2 e^{-2 t}-2 e^{-8 t} .
$$

A test kitérése az indulástól számított 1 másodperc időpillanatban

$$
x_{p}(1)=2 e^{-2}-2 e^{-8} \approx 0,27(m) .
$$

Megjegyzés. Egy $m$ tömegű harmonikus rezgőmozgást végző testre $\frac{1}{10} m g s i n t$ nagyságú periodikus gerjesztő erő hat, ahol $g$ a gravitációs gyorsulás $\left(g \approx 10 \frac{\mathrm{m}}{\mathrm{s}^{2}}\right)$. Az egyszerüség kedvéért a csillapítástól eltekintünk. Ekkor a test mozgását leíró differenciálegyenlet: $\ddot{x}(t)=-\omega^{2} \cdot x(t)+\sin t$, ahol $x(t)$ a test kitérése az idő függvényében, az $\omega$ arányossági tényező a körfrekvencia, melynek nagysága $2 \frac{1}{s}$. A test kitérése $t=0 \mathrm{~s}$ időpillanatban 0 méter, a sebessége ugyanekkor $\frac{7}{3} \frac{m}{\mathrm{~s}}$. Adjuk meg a test kitérését az idő függvényében! Határozzuk meg a test kitérését a $t=\frac{\pi}{2} s$ időpillanatban!

Megoldás. A következő másodrendü, állandó együtthatós, lineáris, inhomogén differenciálegyenletet kell megoldani:

$$
\ddot{x}(t)+4 x(t)=\sin t .
$$


Elöször a homogén egyenlet általános megoldását keressük meg. A karakterisztikus egyenlet $\left(\right.$ ahol $\left.x(t)=e^{\lambda t}\right)$, illetve annak gyökei:

$$
\begin{gathered}
\ddot{x}(t)+4 x(t)=0, \\
\lambda^{2}+4=0, \\
\lambda= \pm 2 i,
\end{gathered}
$$

amelyből a homogén egyenlet általános megoldása:

$$
x(t)=C_{1} e^{0 t} \sin 2 t+C_{2} e^{0 t} \cos 2 t=C_{1} \sin 2 t+C_{2} \cos 2 t, \text { ahol } C_{1}, C_{2} \in \mathbb{R} .
$$

Ezt követően az inhomogén egyenlet partikuláris megoldására próbafüggvényt írunk fel (nincs rezonancia, a feladat egy nagyon egyszerü esetet tárgyal):

$$
x_{p}(t)=A \sin t+B \cos t
$$

Ennek deriváltjait behelyettesítve az eredeti inhomogén egyenletbe, majd az együtthatókat egyeztetve meg tudjuk határozni azok értékeit:

$$
\begin{gathered}
\dot{x}_{p}(t)=A \cos t-B \sin t, \\
\ddot{x}_{p}(t)=-A \sin t-B \cos t \\
-A \sin t-B \cos t+4(A \sin t+B \cos t)=\sin t, \\
A=\frac{1}{3} ; B=0 .
\end{gathered}
$$

Tehát az inhomogén egyenlet partikuláris megoldása:

$$
x_{p}(t)=\frac{1}{3} \sin t
$$

A feladatban szereplő inhomogén differenciálegyenlet megoldását a homogén egyenlet általános megoldásának és az inhomogén egyenlet partikuláris megoldásának összegeként kapjuk:

$$
x(t)=C_{1} \sin 2 t+C_{2} \cos 2 t+\frac{1}{3} \sin t, \text { ahol } C_{1}, C_{2} \in \mathbb{R} .
$$

A kezdeti feltételek miatt szükség van a sebesség-idő függvényre is, emiatt deriváljuk az elöbbi függvényt:

$$
\dot{x}(t)=2 C_{1} \cos 2 t-2 C_{2} \sin 2 t+\frac{1}{3} \cos t
$$

A test kitérése $t=0 \mathrm{~s}$ időpillanatban 0 méter, a sebessége pedig $\frac{7}{3} \frac{m}{\mathrm{~s}}$, vagyis $x(0)=0$ és $\dot{x}(0)=\frac{7}{3}$. Ezeket behelyettesítve az $x(t)$ általános megoldásba, illetve annak deriváltjába:

$$
\left.\begin{array}{c}
C_{2}=0 \\
2 C_{1}+\frac{1}{3}=\frac{7}{3}
\end{array}\right\} .
$$


Ebből $C_{1}=1$ és $C_{2}=0$ adódik, tehát a kezdeti feltételeknek megfelelő partikuláris megoldás:

$$
x_{p}(t)=\sin 2 t+\frac{1}{3} \sin t
$$

A test kitérése az indulástól számított $\frac{\pi}{2}$ másodperc időpillanatban:

$$
x_{p}\left(\frac{\pi}{2}\right)=\sin \pi+\frac{1}{3} \sin \frac{\pi}{2}=\frac{1}{3}(m) .
$$

\section{3. Összefoglalás}

Egyetemünk hallgatói számára a matematika tanulása gyakran - főleg a korábbi hiányosságaik miatt - nehézségekkel jár. A differenciálegyenletek témakörét sokan az ,értelmetlen” és „érthetetlen” jelzőkkel illetik. Nehéz megtalálnunk azokat a feladatokat és azt a tárgyalásmódot, amely az átlagos hallgató számára érthető. Az előbbi erősen leegyszerüsített gyakorlati alkalmazások segítségével a másodrendü differenciálegyenletek témakörét próbáltuk megvilágítani. A felsorolt példák ugyan - a témakör tulajdonságai miatt - igényelnek némi matematikai jártasságot, de bízunk benne, hogy a hallgatók ezekhez hasonló feladatok áttekintését követően bátrabban nyúlnak majd a felsőbb matematika eszközeihez.

\section{Irodalomjegyzék}

[1] Budó Ágoston: Kísérleti fizika I-III. Tankönyvkiadó Budapest, 1978.

[2] Geda Gábor: Modellezés és szimuláció az oktatásban, Educatio Kht., 2011. https://www.tankonyvtar.hu/en/tartalom/tamop425/0038_informatika_Geda_GaborModellezes_es_szimulacio_az_oktatasban/ch04s05.html

[3] Hatvani László - Pintér Lajos: Differenciálegyenletes modellek a középiskolában. Polygon, Szeged, 1997.

[4] Kurics Tamás: Differenciálegyenletek. ELTE Jegyzet, 2011. http://web.cs.elte.hu/ kuricst/bboard/notes/foldtuddiff_ea.pdf

[5] Ponomarjov, K.K.: Differenciálegyenletek felállítása és megoldása. Tankönyvkiadó, Budapest, 1969.

[6] Scharnitzky Viktor: Differenciálegyenletek. Müszaki Könyvkiadó, Budapest, 2002.

[7] Szaszkó-Bogár Viktor: Közönséges differenciálegyenletek. http://www.staff.u-szeged.hu/ vszaszko/ODE\%2020130902.pdf

[8] Terjéki József: Differenciálegyenletek. Polygon, Szeged, 1997. 